\title{
High functioning autism disorder: marital relationships and sexual offending
}

\author{
Transtorno do espectro do autismo de alto funcionamento: \\ relacionamento conjugal e abuso sexual
}

Clayton Peixoto', Dayla Abss Rondon², Adriana Cardoso', André Barciela Veras ${ }^{1,2}$

\section{ABSTRACT}

Objective: To describe the implications of social inability as a factor that can contribute to sexual abuse in the marriage relationship of people with high-functioning autism spectrum disorder (ASD). Case description: A 30-year-old male sought medical attention complaining of being "very nervous" and have difficulties in family relationships. He was diagnosed with high-functioning ASD based on the DSM-5. Married for over 4 years with a woman diagnosed with histrionic personality disorder (HPD), he asked for her to accompany him in the sessions and help him describe difficulties they had during sexual intercourse. His wife reported feeling

\section{Keywords}

High functioning autism disorder, sexual offending, abusive behavior, married, adult.

\section{Palavras-chave}

Transtorno do espectro do autismo, abuso sexual, comportamento abusivo, casado, adulto. raped in all of her sexual relations with the patient, especially when he could not understand that she did not want sex. Comments: The case study leads us to believe that the social and communicative disability is a complicating factor that can contributes to the occurrence of sexual abuse in marital relationships with individuals with ASD. Social skills training, psychotherapy, and traditional medical therapies should be considered to minimize the risk of occurrence of cases of sexual abuse by individuals with high-functioning ASD against the spouses themselves.

\section{RESUMO}

Objetivo: Descrever implicações da inabilidade social como fator que pode contribuir para o abuso sexual no relacionamento conjugal de pessoas com transtornos do espectro do autismo de alto funcionamento (TEA de alto funcionamento). Descrição do caso: Um homem de trinta anos procurou ajuda médica queixando-se de ser "muito nervoso" e ter dificuldades no relacionamento familiar. Foi diagnosticado com TEA de alto funcionamento com base no DSM-5. Casado há mais de quatro anos com uma mulher diagnosticada com transtorno de personalidade histriônica (TPH), pediu que ela o acompanhasse nas sessões para ajudá-lo a descrever suas dificuldades sexuais. A esposa relatou que se sentia estuprada em todas as relações sexuais com o paciente, especialmente quando ele não conseguia entender que ela não queria fazer sexo. Comentários: Este caso nos leva a acreditar que a inabilidade social e de comunicação é um complicador que pode contribuir para a ocorrência de abuso sexual em relacionamentos conjugais de indivíduos com TEA de alto funcionamento. Treinamento de habilidades sociais, psicoterapia e terapias médicas tradicionais devem ser considerados para minimizar o risco de ocorrência de casos de abuso sexual praticados por indivíduos com TEA de alto funcionamento contra os próprios cônjuges.

1 Federal University of Rio de Janeiro (UFRJ), Institute of Psychiatry.

2 Catholic University Dom Bosco (UCDB).

Address for correspondence: Clayton Peixoto

Av. Venceslau Brás, 71 - Botafogo

22290-140 - Rio de Janeiro, RJ, Brasil

Telephone: (+55 21) 2543-3103

E-mail: claytonpeixoto@yahoo.com.br 


\section{INTRODUCTION}

Autism spectrum disorder (ASD) is a neurological and developmental condition that arises in infancy and is characterized by deficits in social communication and by repetitive and restrictive behaviors and some studies suggest a prevalence of up to 1 case per 80 individuals ${ }^{1,2}$.

The development of sexuality is one of the critical points in the life of a person with ASD because this development occurs atypically, especially because of the inability of this population to communicate ${ }^{3}$. Parents often describe this phase as very difficult and observe a lack of social behavior proportional to other adolescents, which leads them to fear that their children will can become victims or sexual offenders ${ }^{3,4}$. This fear is supported in the literature describing a possible relationship between ASD and sexual abuse ${ }^{4,5}$. Although few empirical studies have explored the theme (and those that have are occasionally described as methodologically flawed $)^{5,6}$, some studies suggest a possible link between the marked inability to understand nonverbal language and instances of sexual abuse involving patients with $\mathrm{ASD}^{7,8}$.

We describe the implications of social inability as a possible contributing factor to sexual abuse in the marital relationship of a patient with high-functioning ASD, because there were no studies that specifically address the issue. Information described here were collected by clinical interviews and through the exchange of information between authors and clinicians.

\section{CASE REPORT}

Male, 30 years. He sought medical attention complaining of being "very nervous". He was becoming irritated easily in the company of his family and was manifesting aggressive behaviors, such as screaming and assaulting his 4-year-old son by pushing and elbowing. He also demonstrated selfharm behavior and self-mutilation (boot nails). He said that he had been "nervous" since childhood and began treatment for anxiety three years ago when the symptoms intensified, but he abandoned the treatment twice. He decided to seek help again because of the suffering that his behavior caused him.

The patient presented severe impairment in his social relations and was unable to provide social or emotional reciprocity, which could be observed during medical visits and through his wife's report. The patient could not make direct eye contact with an interlocutor and spent most of the time looking down. He complained of difficulty understanding language, nonverbal behavior, figurative meanings, irony, and jokes. This difficulty irritated him and increased his isolation from social contact. He had no effect of ASD on language development or cognition and no psychotic symptoms. He had restricted and intense interest in matters that, according to him, did not interest other people. He also reported occasional childish behavior, such as falling on the floor and "flounce" when angry. The patient was diagnosed with high-functioning ASD based on the DSM-5.

The patient had met his wife about five years earlier during college. He initiated the dating with her (an extremely religious woman) and pretended to be of the same religion and to share the same principles and interests. They dated for six months, and during that time she did not notice aggressive behaviors. However, after the wedding, he dramatically changed his behavior and began to act rudely (often screaming and cursing), becoming angry for any reason and being very intolerant, especially with his older son (whom was born in the first year of marriage). His wife had psychiatric treatment with another professional in the same clinic and was diagnosed with histrionic personality disorder (HPD). The patient reported that his first sexual intercourse occurred with his wife, the one person to whom he related sexually and emotionally.

During the sessions, the patient asked his wife to accompany him to help with the description of certain information by reporting the difficulties in their sexual relationship. His wife reported feeling raped in all of her sexual relations with the patient, especially when he could not understand that she did not want sex. According to his wife, during her pregnancies with his two sons, the situation was even more difficult because she felt forced to have sex with the patient up to five times a day. Due to this situation, despite never having been physically assaulted by the patient, she feared being attacked and had problems with her pregnancy. When asked about this situation, the patient did not disbelieve the information but said that he thought she wanted to have relations. After the birth of their second child, the wife decided to cease sexual relations with the patient. No protective measure was necessary, since the abuse had stopped several months ago and since the patient's wife showed a resolute protection to it after the gestational period. The child was accompanied by the children's Psychosocial Care Center.

Couple psychotherapy was indicated for the treatment of problems related to sexuality, but the couple did not begin the treatment. A few months later, the wife opted for divorce. The patients described consented (and signed a free and informed consent term) to the divulgation of this case since preserving their anonymity.

\section{DISCUSSION}

The striking inability of the patient to address the complex and subtle language involved in an intimate relationship 
contributed significantly to his wife feeling sexually abused, especially because he could not understand when she did not want sex. The ability to interpret the social world is not simple for anyone, however this task may be more difficult for people with ASD, since most of them have a compromise of this function with varying degrees of difficulty. In this case there was a moderate difficulty that may be related to disproportionate, intense, and detrimental attitudes ${ }^{9}$. Difficulties in the interpretation of limits combined with the obsessive characteristics of this population can lead to behaviors that are perceived by others as abusive ${ }^{6}$. However, one study noted that there is a tendency only toward sexually inappropriate behavior, not abusive or violent behavior ${ }^{10}$. This aspect can be seen in the case report: the patient did not seem aware of the inappropriateness of his behavior, going so far as to declare that he thought he was doing what his wife wanted.

Among other things, we have to take into account that an abuse is also characterized by the understanding that the victim has of what is to be an abusive behavior. Although this aspect must be judged with extreme care not blame the victim, it is important to consider in this case the possible partial contribution of the wife's histrionic personality on the perception of sexual violence. Since the characteristics of HPD include the exaggerated expression of emotion, dramatic, seductive, and manipulative behavior, and the constant pursuit of attention, caution is required in the interpretation of abusive behavior by the patient ${ }^{11,12}$. Thus, we must consider that the typically sexually provocative behavior of HPD, for which the main purpose is to attract attention rather than to necessarily have intercourse, is not interpreted in this way by a person with ASD. This situation may result in conflict generated by the growing demand for attention that the person with HPD feels she deserves but that the person with ASD is unable to ${ }^{12,13}$. We must also consider that the passive attitude adopted by some women during sex, especially those whose sexual practice is guided by religious dogma, can disturb a person with HPD, who may not feel comfortable when she is not the protagonist of the situation. This may make it possible to see the behavior of her partner as abusive ${ }^{13}$.

Thus, we can understanding that the violence by the patient did not occur due to a deliberate desire to harass or rape but due to his inability to grasp the emotions and feelings of others, even when relating to a person diagnosed with HPD, whose natural tendency would be to exaggerate and enhance these feelings and emotions ${ }^{11}$. This argument is strengthened by the fact that no complaint of any violence was made by the wife after she unilaterally decided to stop having sex with the patient.

The elements of this case make an ethical and legal discussion relevant. What is the role of the clinician when dealing with an explicit report of sexual abuse by the wife of a patient? What should be the ethical and legal consequences? Brazilian law calls for the reporting of cases of violence against children or women ${ }^{14,15}$. Once the child was under psychosocial support because of the reported situation, the necessary steps were designated to the professionals that attended the case. The situation of his wife was more complex because the abuse arose from the patient misunderstanding of the real will of his wife, who used to feel abused in a consented marital relationship she wanted to maintain. After informing the patient and his wife of the legal aspects of aggressions and sexual abuse, analyzing the conflicting aspects of the case, we chose not to immediately report the situation to authorities. At the time of follow-up, the wife was able to contain the patient, which in turn did not commit other abuses.

\section{CONCLUSION}

Given the information presented here, we can see the importance of the study of the sexuality of people with ASD, especially in the marital relations context. In that case, we understand that the social inability was an element that contributed to the complaint of sexual abuse, but such abuse did not happen in a voluntary or conscious way. For that reason similar cases should be analysed with caution, since it would be wrong to attribute the abusive behaviour as the standard for people with ASD. In similar cases measures such as the inclusion of the person with ASD in a program of social skills training, psychotherapeutic treatment aimed at broadening awareness of the individual's behavior, and recommended medical therapies (especially when comorbidities occur) can help in the prevention of sexual abuse in social relationships with marital bond.

\section{INDIVIDUAL CONTRIBUTIONS}

Clayton Peixoto - Had substantially contributed to interpretation of data; had substantially contributed to drafting the article; and had given the final approval of the version to be published.

Dayla Abss Rondon - Had substantially contributed to conception and design and interpretation of data; had substantially contributed to revising it critically for important intellectual content; and had given the final approval of the version to be published.

Adriana Cardoso - Had substantially contributed to analysis and interpretation of data; had substantially contributed to revising it critically for important intellectual content; and had given the final approval of the version to be published. 
André Barciela Veras - Had substantially contributed to analysis and interpretation of data; had substantially contributed to revising it critically for important intellectual content; and had given the final approval of the version to be published.

\section{REFERENCES}

1. Wing L. The continuum of autistic characteristics. In: Schopler E, Mesibov GB. Diagnosis and assessment in autism. New York: Plenum Press; 1996. p. 91-110.

2. Wilson CE, Gillan N, Spain D, Roberston D, Roberts G, Murphy CM, et al. Comparison of ICD-10R, DSM-IV-TR and DSM-5 in an Adult Autism Spectrum Disorder Diagnostic Clinic. J Autism Dev Disord. 2013;43(11):2515-25.

3. Stokes M, Newton N, Kaur A. Stalking, and social and romantic functioning among adolescents and adults with autism spectrum disorder. J Autism Dev Disord. 2007;37(10): 1969-86.

4. Chan J, John RM. Sexuality and sexual health in children and adolescents with autism. J Nurse Pract. 2012;8(4):306-15.

5. Bjørkly S. Risk and dynamics of violence in Asperger's syndrome: a systematic review of the literature. Aggress Violent Behav. 2009;14:306-12.
6. Burdon L, Dickens D. Asperger syndrome and offending behavior. Learn Disabil Pract. 2009;9:14-20.

7. Allen D, Evans C, Hider A, Hawkins S, Peckett H, Morgan H. Offending behaviour in adults with asperger syndrome. J Autism Dev Disord. 2008;38(4):748-58.

8. Haskins BG, Silva JA. Asperger's disorder and criminal behavior: forensic-psychiatric considerations. J Am Acad Psychiatry Law. 2006;34(3):374-84.

9. Howlin P. Autism and Asperger syndrome: preparing for adulthood. 2nd ed. New York: Rourledge; 2004

10. Ray F, Marks C, Bray-Gareton H. Challenges to treating adolescents with Asperger's syndrome who are sexually abusive. Sex Addict Compulsivity. 2004;11:265-85.

11. Sadock BJ, Sadock VA. Compêndio de psiquiatria: ciência do comportamento e psiquiatria clínica. 9th ed. Porto Alegre: Artmed; 2007. p. 1299-300.

12. Nunes CHSS, Hutz CS. Construção e validação de uma escala de extroversão no modelo dos cinco grandes fatores de personalidade. Psico-USF. 2006;11:147-55.

13. Disney KL, Weinstein Y, Oltmanns TF. Personality disorder symptoms are differentially related to divorce frequency. J Fam Psychol. 2012;26(6):959-65.

14. Brasil, Lei 8.069 de 13 de Julho de 1990. Available in: http://www.planalto.gov.br/ccivil_03/leis/L8069.htm. Access on: Jul. 15, 2016.

15. Brasil, lei 10.778 de 24 de Novembro de 2003. Available in: http://www.planalto.gov.br/ ccivil_03/leis/2003/L10.778.htm. Access on: Jul. 15, 2016. 